\title{
ORAÇÃO DO FIM-DE-SEMANA: uma análise linguística
}

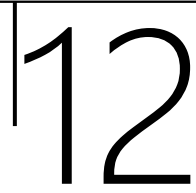

\section{WEEKEND PRAYER: a linguistic analysis}

\author{
MENDES, Marcos Flávio Ribeiro \\ Mestre em Letras pela Universidade do Vale do Rio Verde - UNINCOR \\ E-mail: mflaviomendes@hotmail.com \\ CRISTOVÃo, Assunção \\ Doutora em Linguística e Língua Portuguesa pela UNESP/Araraquara \\ Docente Pesquisadora do PPG Linguística da Universidade de Franca/UNIFRAN \\ E-mail: assuncao.cristovao@gmail.com \\ ORCID ID: https://orcid.org/0000-0002-1304-1106
}

\section{RESUMO}

Este artigo alia alguns dispositivos teóricos da Análise do Discurso de linha francesa (AD) com alguns elementos da Linguística Textual, com a finalidade de demonstrar estratégia discursiva e publicitária veiculada na mídia para despertar o humor e, provavelmente, estimular o consumo de cerveja. Nos textos parodísticos, o humor se revela axiomático - um oportuno e vantajoso instrumento persuasivo.

Palavras-chave: Análise do Discurso; linguística; paródia; estratégias.

\section{ABSTRACT}

This article combines some theoretical devices of French-line Discourse Analysis (DA) with some elements of Textual Linguistics, in order to demonstrate a discursive and advertising strategy conveyed in the media to awaken humor and, probably, stimulate beer consumption. In parodic texts, humor is axiomatic - an opportune and advantageous persuasive instrument.

Keywords: Discourse Analysis; linguistics; parody; strategies.

\section{INTRODUÇÃO}

A proposta desse trabalho é realizar uma investigação do enunciado intitulado Oração do fim de semana para, a partir da utilização de um método heterogêneo de análise, em que se utilizam alguns elementos da Linguística Textual com alguns pressupostos da Análise do Discurso de linha francesa (AD), encontrar sentidos na 
paródia de um cartaz publicitário que se utiliza, como texto fonte, de duas orações da esfera religiosa. Inscrito no gênero textual/discursivo cibercartaz ${ }^{1}$, o objeto analisado apresenta dois enunciados escritos do domínio religioso bíblico que se maximizam com um enunciado imagético. O conteúdo comunicativo dos textos faz apologia ao consumo da cerveja.

O córpus investigado foi veiculado em diversos sites, geralmente situados no domínio do humor, ao lado de curiosidades e entretenimentos; também foi propagado nas redes sociais (Twitter, Youtube, Facebook e outros). Trata-se de um cibercartaz contendo dois textos dispostos em uma propaganda ${ }^{2}$, que não trazem quaisquer informações identificadoras de origem (seja autor, local, data de produção, marca de produto); portanto, trata-se de um cibercartaz ${ }^{3}$ apócrifo. Nesse objeto enunciativo, encontramos dois textos apologéticos, confeccionados humoristicamente com 0 recurso estilístico da paródia, arremedando duas orações bíblicas, respectivamente, o Salmo 23 e a prece do Pai Nosso.

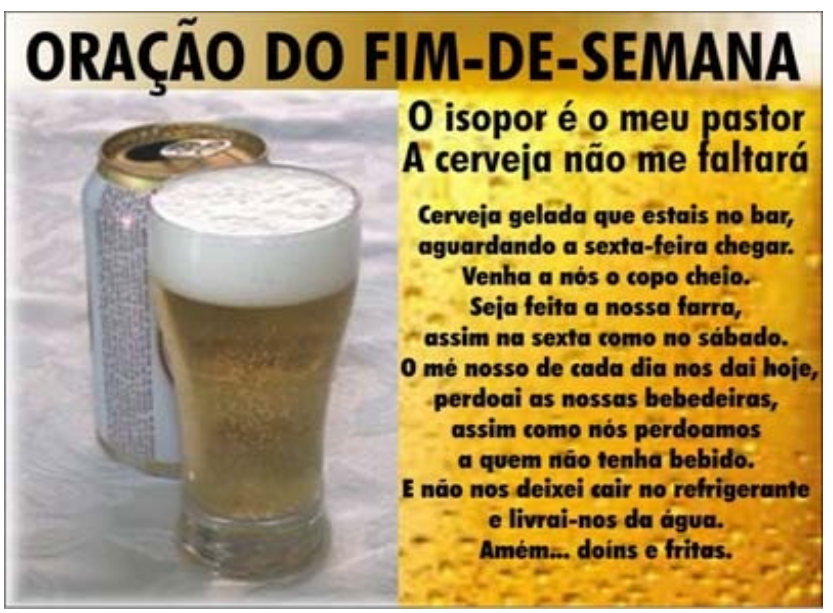

Fonte: https://www.reddit.com/r/DiretoDoZapZap/comments/bcinob/ora\%C3 \%A7\%C3\% A3o_do_fim_de_semana/. Acesso em: 01 dez 21

\footnotetext{
${ }^{1}$ Mesmo não o encontrando em nenhum glossário acadêmico, vislumbrou-se pertinente classificá-lo como cibercartaz, por sua característica de circular somente em domínio virtual.

2 No domínio midiático-publicitário, preceitua-se a propaganda o ato de divulgar ideias, conceitos e valores sem fins lucrativos, ao passo que a publicidade é divulgá-los com o objetivo de lucro por parte do anunciante. Porém, neste artigo, os termos terão sinonímia.

${ }^{3} \mathrm{Em}$ pesquisa na Internet, encontraram-se mais versões do cibercartaz com o mesmo título, algumas também apócrifas e outras com identificação da autoria e/ou da marca da cerveja. Embora tais versões tragam variações estruturais linguístico-semióticas, todas constituem parodias do Salmo 23 e da prece do Pai Nosso, manifestando, a priori, a intenção de causar humor; o domínio por onde veiculam permite essa inferência.
} 
Para analisar esse cibercartaz, parte-se do propalado jargão popular: "a propaganda é a alma do negócio". Portanto, pode-se hipotetizar que essa publicidade não está em circulação por mero interesse de fazer rir; não será exagero presumir a existência de um estratagema escuso por detrás desses textos parodiados. Logo, essa investigação pretende desvendar, se possível, tal dissimulação inserida no anúncio e mostrar o artifício utilizado pela publicidade para persuadir os leitores, levando-os tanto a divulgar o cibercartaz como também a consumir a bebida cerveja.

Esse simulacro parodístico evidencia uma estratégia muito comum do ramo publicitário, que, através da intertextualidade, possibilita uma chance maior de alcançar o propósito traçado. A artimanha, bastante comum na seara da publicidade, neste caso, consiste em alterar/adulterar um texto-fonte, ou seja, de metamorfosear um texto já existente em outro com uma "vestimenta" diferente; ou então de utilizar a roupagem de um gênero textual em outro.

A paródia das respectivas orações apresenta fácil compreensão, já que está escrita numa linguagem prosaica, não se distanciando estruturalmente dos textos-fonte, cuja estratégia proporciona que o leitor os recupere através de pistas, como a forma estrutural e algumas expressões lexicais. O contato com os dois textos provoca efeito de humor. Não se pode negar que os enunciados fazem apologia à cerveja com criatividade, provocando efeito de humor. Portanto, o que está explícito (dito) compreende o engendro cômico, isto é, o ardil talento de um sujeito anônimo desconstrói o sentido de duas orações conhecidas pela comunidade de fé cristã, provocando humor ao enaltecer a cerveja. A utilização de conhecimento metagenérico ${ }^{4}$, sobretudo o recurso linguístico da intertextualidade ${ }^{5}$, oferece fulcro para o texto do cartazista.

Não obstante, vale pontuar que a nova "vestimenta" das preces Salmo 23 e oração do Pai Nosso concorre como um engendro sarcástico perante a esfera conservadora de religiosidade cristã. Para alguns sectários do cristianismo, esse "talento" linguístico representa(ria) um ultraje às palavras sacrossantas, de modo que tal paródia manifesta(ria) uma verdadeira profanação de textos sagrados. Essa concepção da fé cristã se fundamenta nos alicerces das religiões, ou seja, nos seus dogmas, nos costumes e nas tradições - portanto, para parte de adeptos cristãos, aceitar esse tipo de humor zombeteiro seria violar os preceitos religiosos

\footnotetext{
${ }^{4}$ Atributo que se tem de confeccionar um gênero textual com características de outro $(\mathrm{KOCH}, 2004)$.

${ }^{5} \mathrm{~A}$ intertextualidade ocorre quando, em um texto, outro texto (pré-existente) é revelado, denominado texto-fonte - um texto que circula na memória sociocultural de uma coletividade $(\mathrm{KOCH}, 2008)$. Vale apontar que, segundo Marcuschi (2008, p. 129), "há hoje um consenso quanto ao fato de se admitir que todos os textos comungam com outros textos, ou seja, não existem textos que não mantenham algum aspecto intertextual, pois nenhum texto se acha isolado e solitário".
} 
da Igreja. Por isso que, sob essa concepção, essas paródias não poderiam ser consideradas "arte", mas sim uma injúria ao texto religioso bíblico.

Para compor esse cenário discursivo, ainda é oportuno reportar campanhas da área médica e governamental e sociais sobre o consumo de bebidas alcoólicas. Dados comprovam que o consumo "não adequado" de bebidas de teor alcoólico é nocivo à saúde, provocando graves consequências, como: hipertensão, acidente vascular cerebral, diversos tipos de câncer, e outras enfermidades. Esse consumo demasiado muitas vezes se transforma no estopim para a incidência de conflitos civis e/ou familiares, ainda se credenciando como o responsável por grande parte dos acidentes de trânsito em vias urbanas e rodovias nos fins de semanas.

Assim, diante desse palco conflitante de ideologias, os discursos engendrados no objeto propagandístico apócrifo são analisados, proporcionando, simultaneamente, ao receptor, a oportunidade de formular uma leitura capaz de captar os possíveis efeitos de sentido oriundos do texto.

\section{LER E COMPREENDER}

Como conceito primaz, entendemos que a leitura pode ser conceituada como um ato volitivo em busca de conhecimentos/informações, em que se captam e se decodificam as relações existentes no mundo - este concebido como a exterioridade infinita que circunda o leitor. Tal definição encontra fundamento no preceito bakhtiniano que certifica que "compreender é opor à palavra do locutor uma contrapalavra" (BAKHTIN, 1995, p. 132, grifos do autor) engendro em que se busca construir um sentido por meio das "sinalizações" textuais ajustadas pelo autor/locutor e incorporado com os conhecimentos de mundo do leitor, assim, esse assume uma atitude "responsiva ativa" no processo sociocognitivo-interacional (KOCH \& ELIAS, 2010). Cabe ainda pontuar que Bakhtin (1995) elucida que se pode chegar ao "não dito", por intermédio do "dito" em uma relação de conexões com a exterioridade, uma vez que é possível perceber na forma camuflada e intransparente da estrutura enunciativa alguns implícitos e pressuposições - isso corrobora que a necessidade de se compreender um texto é fundamental para conseguir alcançar uma leitura coerente, plausível racional.

Assim, reiterando ser a leitura um ato individual, volitivo, que se processa no intelecto do receptor/leitor, segundo Koch \& Elias (2010), ela se inicia com a decodificação de signos linguísticos (conteúdo cotextual) e que se completa com a interação discursiva (conteúdo contextual). Tal 
atividade exige do leitor muita atenção e esforço, impondo o uso constante de sua bagagem cognitiva (conhecimento enciclopédico, linguístico, etc.). É fundamental que o leitor posicione responsivamente diante do texto; produza inferências para preencher lacunas; siga as orientações e as pistas do produtor no corpo do texto; estabeleça relação entre o verbal e o nãoverbal; posicione um propósito para a leitura; e, enfim, efetue uma construção de sentido para o texto (KOCH \& ELIAS, 2010). Salienta-se que o autor/produtor deve possuir um conjunto de conhecimentos de mundo, principalmente de estratégias linguísticas, para confeccionar um enunciado revestido de lisibilidade, e, assim, alcançar êxito no intento do discurso. Também o papel do leitor é substancial para o efeito de sentido. O conhecimento linguístico prévio e a sua bagagem enciclopédica são fundamentais para a construção de sentido esperado pelo autor/locutor. Portanto, espera-se que o leitor "processe, critique, contradiga ou avalie a informação que tem diante de si, que a desfrute ou a rechace, que dê sentido e significado ao que lê"' (SOLÉ, 2003, apud KOCH \& ELIAS, 2010, p. 13); de tal modo que essa leitura alcance a proficiência discursiva.

\section{INTERTEXTUALIDADE}

É característica constituinte do texto a intertextualidade. Existem muitos conceitos que definem a intertextualidade, os quais proporcionam a compreensão de que um texto não é puro, homogêneo, imaculado, genuíno. Conforme os preceitos bakhtinianos, um texto é prenhe de palavras de outros. Norteada por essa mesma concepção, a linguista Júlia Kristeva pontua que "qualquer texto se constrói como um mosaico de citações e é a absorção e a transformação de um outro texto" (KRISTEVA, 1974, apud $\mathrm{KOCH}, 2008$, p. 85). Também corroborando a essência "híbrida" do texto, Koch (2004, p. 145, grifo nosso) assevera que a intertextualidade é "a (inevitável) presença do outro naquilo que dizemos ou escrevemos". Portanto, a intertextualidade pode ser entendida como um diálogo entre textos; pragmaticamente, não será obstante que possa ser concebida como o "estranho" invadindo o original. De tal modo, para que se possa contemplar o efeito de sentido de um texto é necessário que se recupere o texto-fonte, ou seja, que se reconheça o texto precedente do qual originou o novo texto - remodelado parcial ou integralmente.

Ainda é necessário apontar que a intertextualidade também abrange o âmbito dos gêneros - a intergenerecidade ${ }^{6}$. Tal fenômeno linguístico-

${ }^{6}$ Na seara da Linguística Textual, pode ocorrer a intertextualidade intergêneros, ou seja, um gênero pode trazer consigo outros gêneros. Exemplo: um cartaz pode estar constituído por um salmo, uma 
estilístico ocorre quando um texto de gênero específico é confeccionado em outro; por exemplo: uma prece (oração), que tem um rol de peculiaridades morfossintáticas, é utilizada em um cartaz/cibercartaz de propaganda, que por sua vez, possui especificidades distintas do gênero oração, como: estrutura, informatividade, publicidade, persuasão e, sobretudo, funcionalidade. Koch \& Elias (2008, p. 55) postulam que "a escolha do gênero é, pois, uma decisão estratégica, que envolve uma confrontação entre os valores atribuídos pelo agente produtor aos parâmetros da situação (...) e os usos atribuídos aos gêneros do intertexto", ou seja, o locutor, através de seu ardil estilístico, analisa e escolhe qual o gênero mais eficaz para o seu ato enunciativo.

\section{GÊNEROS}

Na trilha sócio-histórica da linguagem, em que predomina o caráter interativista, Marcuschi (2008) compreende que os gêneros textuais são enunciados (orais ou escritos) quase estabilizados, situados histórico e socialmente, que, nos dias atuais, podem ser também observados como uma categoria cultural, uma forma de ação e organização social - corolário de que que não há gênero sem texto e texto sem gênero. Tal concepção está fundada nos postulados sociointerativistas de Bakhtin (2000) e deriva do preceito bakhtiniano de gênero:

Todas as esferas da atividade humana, por mais variadas que sejam, estão sempre relacionadas com a utilização da língua [...] mas cada esfera da utilização da língua elabora seus tipos relativamente ${ }^{7}$ estáveis de enunciados, sendo isso que denominamos gêneros de discurso. (BAKHTIN, 2000 , p. 279, grifo do autor)

O gênero cartaz $^{8}$ denota uma importante modalidade para a comunicação. Pela sua praticidade, figura como um dos gêneros mais utilizados pela imprensa publicitária. Caracteriza-se pela linguagem resumida e objetiva, pelo uso de recursos imagéticos,e pelo dom persuasivo das palavras - e essa peculiaridade traduz-se em fonte de poder. É comum encontrarmos esse tipo de veículo de comunicação nas ruas, estabelecimentos comerciais, repartições públicas e culturais, e em

oração, uma paródia, um provérbio, uma piada, uma charge, etc. Fundamental é perceber a funcionalidade do gênero - é ela que identificará o gênero textual atuante (Marcuschi, 2008).

${ }^{7}$ O vocábulo relativamente, segundo Fiorin, "indica uma imprecisão das características e das fronteiras dos gêneros" (FIORIN, 2006, p. 64).

${ }^{8} \mathrm{http}: / /$ www.brasilescola.com/redacao/o-cartaz.htm. Acesso em 22/05/2013. 
outros diversos lugares, já que tem função social - informa, ensina e persuade. Portanto, quanto a essa função, fica evidente que o objetivo do cartaz é atuar como um informativo - esse caráter informativo o qualifica como um gênero divulgador de eventos, campanhas e produtos, assumindo a identidade de um instrumento propagandístico-publicitário; e assim, sob a orientação socio-interativa (bakhtiniana) da língua(gem), obviamente, ideológico.

Embora tenha se consagrado a sua materialização em folha de celulose com circulação em espaços físicos, atualmente, o território que se tem mostrado útil e célere para divulgação do cartaz é a Internet, ambiente no qual tal gênero muda de suporte ${ }^{9}$, assumindo o formato virtual. Assim, este artigo optou por denominar essa versão virtual de cibercartaz.

\section{PARÓDIA - RECURSO LINGUÍSTICO-ESTILÍSTICO}

A paródia ${ }^{10}$ utiliza um recurso linguístico-estilístico em que se imita uma obra, ou seja, trata-se de uma recriação "insubordinada" de uma obra (geralmente conhecida), confeccionada com teor crítico e/ou humorístico. E um recurso linguístico-estilístico muito usado pela mídia, com as mais variadas intenções. De considerável criatividade, a artimanha constitui em apoderar-se de um gênero e/ou texto conhecido para que esse seja metamorfoseado, isto é, empresta-se a estrutura do texto-fonte alterando o seu sentido original, para construir um novo texto com outro sentido. Geralmente de caráter cômico ou satírico, a paródia age sobre um assunto, polêmico ou não, que já estivera ou que esteja em evidência. O seu valor linguístico e social é comprovado pela Lei $\mathbf{9 . 6 1 0} / \mathbf{9 8}{ }^{11}$, que disciplina sobre os direitos autorais: Art. 47 - São livres as paráfrases e paródias que não forem verdadeiras reproduções da obra originária nem the implicarem descrédito.

No domínio acadêmico, Fiorin explicita que "a paródia é uma imitação de um texto ou de um estilo que procura desqualificar o que está sendo imitado, ridicularizá-lo, negá-lo" (FIORIN, 2006, p. 42). Na concepção bakhtiniana da linguagem, encontramos o processo de carnavalização, que

\footnotetext{
9 "locus físico ou virtual com formato específico que serve de base ou ambiente de fixação do gênero materializado como texto" (MARCUSCHI, 2008, p. 174).

${ }^{10}$ Sugestão da leitura: PARÓDIA, no E-Dicionário de Termos Literários, de Carlos Ceia. Disponível em: http://www.edtl.com.pt/index.php?option=com_mtree\&task=viewlink\&link_id=353\&Itemid=2.

Acesso: 25/05/2011.

${ }^{11} \mathrm{Na}$ esfera jurídica, a questão da autoria, paráfrase e paródia não é pacífica. Há doutrina que postula que, mesmo no caso de paráfrases e paródias, faz-se necessária prévia autorização do autor da obra original (Art. 29, inciso III, da Lei no 9.610/98) e há corrente de doutrinadores afirmando que as paráfrases e paródias dispensam a prévia permissão do autor, valorando a expressão "livres" do Art. 47 da mesma Lei, favorecendo uma interpretação lato sensu.
} 
representava uma crítica aos gêneros consagrados. Assim, a ideologia materializava-se em enunciados sem as mordaças dos cânones - uma insurreição de palavras livres e rebeldes.

O presente, a atualidade enquanto tal, o 'eu próprio', os 'meus contemporâneos' e o 'meu tempo' foram originariamente 0 objeto de um riso ambivalente, objetos simultâneos de alegria e de destruição. E é aqui precisamente que se forma uma nova atitude radical em relação à língua e à palavra. Ao lado da representação direta - da ridicularização da atualidade vivente - floresce a parodização e a travestização de todos os gêneros elevados. (BAKHTIN, 1990, p. 412, grifos do autor)

No objeto de análise em questão, o cibercartaz sobre a cerveja, observa-se que o gênero textual prece/oração ${ }^{12}$ figura somente como uma roupagem para a paródia, uma vez que o efeito de sentido original dos textos-fonte é alterado significativamente, ou seja, os significados dos textos bíblicos e também orações cristãs, "Salmo 23" e "Pai Nosso", são destituídos de conteúdo enunciativo religioso, para serem reconstruídos parodicamente no texto Oração do fim-de-semana.

\section{O PODER DO DISCURSO}

Segundo Bakhtin (1995), o discurso nada mais é do que promover a ação da palavra com o exterior, ou seja, é fomentar a inter-ação da palavra, suscitando ditos e não-ditos. Portanto, sob esse entendimento, o discurso não objetiva outro alvo a não ser o "outro". De tal modo, a língua torna-se o veículo necessário e ideal para tal realização - a propaganda é um instrumento eficaz nessa empreita, uma vez que precisa atingir o outro a fim de persuadi-lo, convencê-lo. Já o "poder" está presente nos mais variados âmbitos, e, segundo Barthes (1983, p. 12), é através da linguagem que ele se constitui: "Esse objeto em que se inscreve o poder, desde toda a eternidade humana, é: a linguagem - ou, para ser mais

\footnotetext{
${ }^{12}$ A prece/oração tem finalidade de agradecer, louvar ou pedir para um espírito (alma) ou divindade. Segundo consta no Dicionário de Gêneros Textuais, o conceito do gênero oração é: "ORAÇÂO (v. DISCURSO, JACULATÓRIA, HOMILIA, OFÍCIO, PRECE, PRÉDICA, REZA, SERMÃO): súplica, pedido dirigido a Deus, a santo, a uma divindade. $O$ assunto pode ser o mais variado possível, desde pedidos de saúde para quem reza ou para outras pessoas, obtenção de graças, agradecimentos, etc. Mas geralmente predomina o estilo direto de uma interlocução com Deus, um santo ou divindade, de maneira respeitosa e, muitas vezes, usando-se um tratamento formal, como Vós, Senhor, etc. Oração pode ser sinônimo de Discurso (v.), sermão (v.), prédica (v.) ou homilia (v.), constituindo uma fala eloquente, de cunho religioso, moral, etc., que, em geral, é proferida em ocasião solene, no púlpito, pelo pregador - um sacerdote, um pastor, etc." (COSTA, 2008, p. 160)
} 
preciso, sua expressão obrigatória: a língua". Corroborando essa orientação sobre o poder da língua(gem), "a história não cessa de nos ensinar - o discurso não é simplesmente o que traduz as lutas ou sistemas de dominação, mas aquilo por que, pelo que se luta, o poder do qual nos queremos apoderar" (FOUCAULT, 2010, p. 10). Assim, o poder traduz-se no êxito em fazer com que tal discurso persuada, uma vez que, na concepção sociointeracionista, a língua é ideológica por excelência.

\section{O CONTEXTO SÓcIO-HISTÓRICO-IDEOLÓGICO}

Para tecer qualquer comentário sobre o conteúdo enunciativo do cibercartaz faz-se necessário situar o contexto social, histórico e ideológico, ou seja, o momento atual e as condições as quais oportunizaram o advento desse cibercartaz de conteúdo parodístico. De tal maneira que, nada mais pertinente do que fundamentar a Análise do Discurso ${ }^{13}$ com a orientação sociointeracionista da língua(gem), postulada por Bakhtin, quando ele racionaliza: "a palavra está sempre carregada de um conteúdo ou de um sentido ideológico ou vivencial. É assim que compreendemos as palavras e somente reagimos àquelas que despertam em nós ressonâncias ideológicas ou concernentes à vida" (BAKHTIN, 1995, p. 95).

Estabelecida a ancoragem nesse postulado sociointeracionista, para a análise discursiva do cibercartaz deve-se mencionar algumas premissas: que o Brasil teve e tem uma tradição religiosa cristã fundamental para a constituição na cultura brasileira; que as orações/preces se inserem na esfera da religiosidade; que as respectivas orações, Salmo 23 e a prece do Pai Nosso, são conhecidas pela maioria dos brasileiros; que o Brasil é qualificado como um país tropical (de temperatura quente); que seu povo é quase que integralmente sociável e festivo; que, conforme dados estatísticos ${ }^{14}$ e culturais, milhões de brasileiros são assazes apreciadores de cerveja - bebida que também é aclamada como uma "paixão nacional"; que, culturalmente, nos finais de semana (sexta-feira e sábado), os brasileiros gostam de beber cerveja.

\footnotetext{
${ }^{13}$ A Análise do Discurso é um método do domínio da Linguística, que consiste em analisar um texto sua estrutura frástica (co-texto) incorporada, necessariamente, à exterioridade desse texto (contexto sócio-histórico), com o objetivo de compreender as construções ideológicas inseridas no mesmo (ORLANDI, 2005).

${ }^{14}$ OLIVEIRA, Maria Helena. Cerveja: um mercado em expansão. Disponível em:

http://www,bndes.gov.br/Site

BNDES/export/sites/default/bndes_pt/Galerias/Arquivos/conhecimento/bnset/cerveja.pdf. Acesso $25 / 05 / 2013$.
} 


\section{ANÁLISE DO TEXTO ORAÇÃO DO FIM-DE-SEMANA}

Para analisar qualquer discurso é mister que o leitor ative os seus conhecimentos de mundo e a sua memória linguístico-cultural - só assim poderá construir e alcançar o sentido proposto no/pelo texto lido.

O cibercartaz - veículo da propaganda - apresenta-se confeccionado em quatro partes:

1a) cabeçalho: traz o título do texto: ORAÇÃO DO FIM-DE-SEMANA; está escrito com letras maiúsculas, em negrito. Esse estilo gráfico intenciona chamar a atenção do leitor(es), oferecendo uma pista (informação) do conteúdo do texto. No título, o autor enfatiza o tema que será dissertado, aguçando a curiosidade do(s) receptor(es). Ao ler o título, a priori, deduz-se que o texto abordará a esfera da espiritualidade religiosa, pois isso seria o coerente, evidenciaria a normalidade dentro do contexto atual brasileiro - um país que teve e tem forte cultura cristã arraigada na tradição popular e na sua constituição sócio-histórica. Nesse cenário, consequentemente, oração coaduna com religião, de tal maneira que a religiosidade se torna uma conclusão lógica para "pista" explícita que o título carrega. É racional a inferência de se tratar de uma prece em agradecimento, por se vencer mais uma semana de trabalho. É bastante plausível pressupor uma manifestação de gratidão ou de súplica, pedindo saúde e disposição para continuar semana pós semana - pois esse é o procedimento coerente, habitual e, até mesmo, tradicional em uma prece.

2a) o enunciado: "O isopor é meu pastor / A cerveja não me faltará" - nesse texto se evidencia a intertextualidade implícita, com valor de captação ${ }^{15}$. O texto reporta ao Salmo 23 da Bíblia, um dos mais conhecidos da fé cristã: "O Senhor é meu pastor, nada me faltará." A meditação sobre o enunciado-fonte suscita considerável metáfora filosófico-religiosa. Não obstante, ao trilhar por essa concepção, pode-se presumir que, segundo preceitos bíblicos, é função de todo pastor zelar de seu rebanho, e, sendo assim, supor que esse empenhará com esmero o seu ofício. Daí a confiança nos provimentos dele, ou seja, nada há de faltar sob a guarda do protetor. Mas essa presunção só se dará para o leitor com conhecimento dessa esfera religiosa. No cibercartaz, o parodista tem a ousadia sarcástica de elevar o "isopor" à condição de pastor, ou seja, o autor exalta o recipiente de $\mathrm{EPS}^{16}$ como se fosse guia, guardião e provedor, esperando, de tal modo,

15 Intertextualidade que provoca no texto-fonte adulterações parciais, ou seja, se produz uma paráfrase, que exige do leitor a recuperação do texto original, para que se alcance o sentido engendrado e proposto pelo novo texto (KOCH e ELIAS, 2008).

${ }^{16}$ Poliestireno expandido; o mesmo que isopor e estiropor. 
que, onde houver isopor, cerveja não haverá de faltar. Essa evocação é prova da confiança que se pode ter no "isopor", de que esse não deixará de prover a cerveja gelada. Linguísticamente, torna-se visível o uso estratégico do détournement ${ }^{17}$ na produção intertextual. Essa estratégia do produtor exige que o leitor acione a sua bagagem de conhecimentos e busque na memória sócio-cultural a recuperação do texto-fonte, para que consiga condições de compreender o efeito de sentido proposto no novo enunciado. Quando utiliza-se o détournement, ocorre um "estranhamento" do texto-fonte, que provoca uma ruptura com o "normal", com o óbvio; geralmente, como consequência, irrompe o humor. Esse deslocamento do convencional para o extravagante provoca o efeito de sentido burlesco é a configuração da paródia.

3a) a paródia da oração do Pai Nosso - é sabido que a oração do Pai Nosso é a prece mais conhecida da comunidade cristã, e talvez, uma das mais recitadas do mundo. O texto-fonte está escriturado na Bíblia, situado no Novo Testamento, relatado nos evangelhos de Mateus (6. 9-13) e Lucas (11. 2-4); e diz respeito ao ensinamento de Jesus quanto à maneira de orar (agradecer e pedir) a Deus. Já estabelecido o conceito de oração no domínio dos gêneros textuais, não somenos é defini-lo lexicalmente. Segundo a enciclopédia Larousse Cultural (p. 4400), o conceito léxico é: "ORAÇÃO sf (do lat. oratio, orationis.) 1. Súplica dirigida a Deus ou a qualquer entidade sobrenatural. 2. Ação de orar, invocação, reza, prece"(...). Linguisticamente, o exame dos enunciados parodísticos da Oração do Fim-de-Semana evidencia a intertextualidade implícita de valor de subversão ${ }^{18}$. É o que se configura conforme a análise enunciativa, credenciada pela bagagem de conhecimentos de mundo:

- "Cerveja gelada que estais no bar, aguardando a sexta-feira chegar" (texto-fonte, doravante: tf: "Pai Nosso, que estais nos céus, santificado seja o vosso Nome") - o autor categoriza a cerveja gelada como um ser superior, sublime; classifica o bar como o paraíso celeste, de onde essa bebida aguarda o fim de semana para saciar a sede do locutor.

- "Venha a nós o copo cheio" (tf: "Venha a nós o vosso reino") - o produtor suplica que se sirva a cerveja com abundância - "sem miséria" uma peculiaridade de cervejadas.

- "Seja feita a nossa farra, assim na sexta como no sábado." (tf: "Seja feita a vossa vontade, assim na terra como nos céus.") - o parodista

17 Termo usado geralmente para o processo de criação de um enunciado com "traços" marcantes de um outro já existente e conhecido, porém, com sentido enunciativo diferente do enunciado-fonte, ou seja, com "desvio" de significação. (KOCH e ELIAS, 2009, p. 105).

18 Produz no texto-fonte alteração, inversão ou contraposição do sentido original, ou seja, "retextualiza" o enunciado-fonte, causando nesse um novo "enquadre", um outro sentido (Koch; Elias, 2009, p. 107 - 108). 
insurge contra as regras convencionais e institucionais, já que o importante é que se satisfaça a vontade dele e do(s) seu(s) companheiro(s), cujo interesse é farrear, nas sextas-feiras e nos sábados - "terra" transformase em "sexta"; e "sábado" é a transmutação de "céus". Biblicamente, o último dia da semana é o dia consagrado ao descanso, mas para os "apreciadores" é dia da farra - um verdadeiro "paraíso". Nas cervejadas, após alguns copos cheios, a farra geralmente ocorre.

- "O mé de cada dia nos dai hoje," (tf: "O pão nosso de cada dia, nos dai hoje.") - a gíria "mé" é um dos sinônimos da bebida aguardente de cana-de-açúcar; não obstante, o lexema adquiriu sinonímia de qualquer bebida alcoólica, compreendendo, assim, a cerveja. Portanto, a rogativa do locutor é para que não falte cerveja para os apreciadores dela, principalmente "hoje", ou seja, no dia em que se reza. Por inferência, todos os fins de semana.

- "Perdoai as nossas bebedeiras, assim como nós perdoamos a quem não tenha bebido." (tf: "Perdoai as nossas ofensas, assim como nós perdoamos aquele que nos tem ofendido") - o solicitante roga o perdão para si e seu(s) companheiro(s), pelas vezes que excederam na bebida, pois eles perdoam aquele que preferiu não se embriagar na ocasião.

- "E não nos deixeis cair no refrigerante, e livrai-nos da água." (tf: "E não nos deixeis cais em tentação, mas livrai-nos do mal.") - o locutor pede para que, caso sobrevenha a ressaca, não se permita a hidratação por refrigerantes e/ou água - isso seria uma "desonra" para qualquer apreciador de cerveja; um motivo para muita zoação.

- "Amém... doins e fritas." (tf: "Amém.") - esse remate atinge o auge do efeito de sentido dessa paródia. Através de uma estratégia sintagmática, o autor remodela o vocábulo "amém" (sinonímia: de acordo, assim seja), inserindo o elemento silábico "doins", como se fosse um pseudosufixo - manobra que incute a representação do grão "amendoim", que junto com as "fritas"19 constituem dois dos principais acompanhantes ("tira-gostos") do ato de beber cerveja. Esse final arremata todo o discurso com o apogeu do humor, corroborando todo o talento do cartazista.

A paródia das duas preces bíblicas citadas revela que o autor possui bagagem de conhecimentos enciclopédicos e linguísticos. A estrutura composicional e estilística do cibercartaz comprova a competência metagenérica e linguística do sujeito-locutor. As alterações provocadas não suprimiram a coesão e a coerência dos textos. O conteúdo discursivo dos enunciados está sequenciado, o que resulta na unicidade do discurso.

Consequentemente, com facilidade configuram-se os textos-fonte percebendo as dicas compreendidas no conjunto enunciativo: o título (nos

\footnotetext{
${ }^{19}$ Termo geralmente designado para a porção de batatas fritas.
} 
dá uma pista importante de que se trata de uma oração); a estrutura sintático-morfológica (no $1^{0}$ texto, as expressões "é o meu pastor" e "não me faltará" remetem ao conhecido Salmo 23; no $2^{\circ}$ texto, a presença das construções gramaticais, como: "que estais", "venha a nós", "nosso de cada dia, nos dai hoje", "assim como nós perdoamos", o vocábulo "Amém" - termo que encerra a maioria das preces cristãs - reportam à prece do Pai Nosso).

4a) a quarta parte: consiste na imagem de um copo no estilo tulipa, cheio de cerveja, conforme a preferência de muitos brasileiros apreciadores dessa bebida, "com colarinho"20. Trata-se de um referente imagético, portanto explícito, que caracteriza o gênero multimodal do cibercartaz, que, por sua vez, possui força persuasiva advinda não apenas do sintático, mas também do semiótico. Por conseguinte, a figura tem papel preponderante no cibercartaz, já que se constitui um signo vivaz, pois ativa sensações, aguça e induz os leitores, consumidores de bebida alcoólica, à vontade de beber cerveja. É a força do imagético no leitor, corroborando 0 adágio popular que uma imagem vale mais do que mil palavras ${ }^{21}$. No plano posterior da tulipa, podemos ver e presumir ser uma latinha de cerveja, cuja marca se encontra oculta - o que também pode comprovar a anonimidade do patrocinador desse cibercartaz.

Cabe pontuar que o plano de fundo em que se inserem as preces é ilustrado por um líquido gaseificado dourado, cuja aparência nos remete à imagem da cerveja numa tulipa.

\section{CONSIDERAÇÕES FINAIS}

Na análise do cibercartaz, o leitor pode produzir inferências e preencher lacunas para hipotetizar o intuito dissimulado no objeto enunciativo, isto é, elaborar uma leitura que permita "enxergar" além do conteúdo frástico, não se limitando só no conteúdo burlesco da paródia. Se no texto existe o intuito humorístico, não obstante pode existir outra intenção camuflada, oculta. Assim sendo, o uso da bagagem de conhecimentos por parte do leitor se faz necessário para uma análise profícua da enunciação, uma vez que ele atua como um co-autor, já que a construção de sentido do texto depende da sua competência enciclopédica

\footnotetext{
${ }^{20}$ Tulipa completa de cerveja/chopp com no máximo dois dedos de espuma.

${ }^{21}$ A relatividade dessa teoria filosófica, segundo Millôr Fernandes, se estabelece em como dizê-la com imagens: "Uma imagem vale mais do que mil palavras. Vai dizer isto com uma imagem" (Disponível em: <http://veja.abril.com.br/270509/millor.shtml>. Acesso em: 04/06/2013).
} 
e de sua idiossincrasia.

É cediço que, no Brasil, o poder das cervejarias no mercado sócioeconômico é indiscutível. Não é difícil notar que os maiores eventos do país têm como um dos patrocinadores uma marca de cerveja - em muitas das festas populares, a presença de uma marca fica evidente.

Observa-se, ainda, que, no domínio da Análise do Discurso, não há discurso neutro - a neutralidade já é um manifesto de "não harmonia", segundo Pêcheux (1997). Assim, o efeito de sentido da enunciação configurada no cibercartaz autoriza a hipótese de não se retratar somente de uma "arte" linguística-literária (paródia) ou de um simples artifício de publicidade (propaganda). Talvez, esse discurso possa refratar a voz "calada" de um grupo social - aqueles que lucram financeiramente com o comércio de cerveja. Portanto, enfatiza-se que, concomitante com o riso que a propaganda provoca, é plausível existir a intenção de apologizar o consumo de cerveja. Ou seja, ainda que se objetive somente provocar humor, essa propaganda seduz o leitor a consumir o produto; e mesmo que ele não beba, propaga o cibercartaz para seus amigos e/ou conhecidos, sem custos, estratégia que, pode-se afirmar, contitui-se como uma eficaz estratégia de marketing.

Atina-se, dessa maneira, que sempre houve e haverá objetivos, condizentes ou não, por detrás de um mero texto, pois não existe um texto exaurido de interpretação. De tal modo, é a intenção da Análise do Discurso entender como a língua(gem) se materializa-se na ideologia e a manifestação dessa na língua(gem). Conforme Pecheux (1997) postula, o linguístico é opaco, existe uma não transparência no "dizer". Segundo ele, "todo enunciado, toda sequência de enunciados é, pois, linguisticamente descritível como uma série (léxico-sintaticamente determinada) de pontos de deriva possíveis, oferecendo lugar à interpretação" (PÊCHEUX, 1997, p. 53, grifo nosso).

\section{REFERÊNCIAS}

BAKHTIN, Mikhail. A estilística contemporânea e o romance. In: Questões de literatura e de estética: a teoria do romance. Trad. Aurora F. Bernardini et al. 2. ed. São Paulo: UNESP; Hucitec, 1990, p. 72 - 84.

. Marxismo e Filosofia da Linguagem. Trad. Michel Larud e Yara Frateschi Vieira. 9. ed. São Paulo: Hucitec, 1995. p. 196.

. Epos e Romance. In: Questões de literatura e de estética:

a teoria do romance. Trad. Aurora F. Bernardini et al. 2. ed. São Paulo: UNESP; Hucitec, 1990, p. 397 - 428. 
. Os Gêneros do Discurso. In: BAKHTIN, M. Estética da Criação Verbal. Trad. Maria Ermantina Galvão; revisão: Marina Appenzeller. 3. ed. São Paulo: Martins Fontes, 2000, p. 277 - 326.

BARTHES, Roland. AULA. Trad. Leyla Perrone-Moisés. São Paulo: Editora Cultrix Ltda., 1983.

BETTIO, Maíra Althoff de. Paródia. disponível em: <http://www.infoescola.com/generos-literários/parodia/>. Acesso em: 25 maio 2013.

CEIA, Carlos. E-dicionários de termos literários. Disponível em: $<$ http://www.edtl.com.pt/index.php?option=com_mtree\&task=viewlink\&li nk_id=353\&Itemid=2>. Acesso em: 25 maio 2013.

COSTA, Sérgio R. Dicionário de gêneros textuais. 2. ed. Belo Horizonte: autêntica, 2009.

DUARTE, Vânia. O Cartaz. Disponível em: <http://www.brasilescola. com/ redação/o-cartaz.htm. Acesso em: 22 maio 2013.

FÁVERO, Leonor L. Paródia e dialogismo. In: FIORIN, José Luiz; BARROS, Diana L. Pessoa de (org.). Dialogismo, polifonia, intertextualidade. 2. ed. São Paulo: EDUSP, 2000, p. 49-62.

FERNANDES, Millôr. A emocionante disputa: palavra $\mathbf{X}$ imagem. Disponível em: <http://veja.abril.com.br/270509/millor.shtml>. Acesso em: 04 jun. 2013.

FIORIN, José Luiz. Introdução ao pensamento de Bakhtin. São Paulo: Ática, 2006.

. Interdiscursividade e intertextualidade. In: BRAITH, Beth (org.). Bakhtin: outros conceitos-chave. São Paulo: Contexto, 2006, p. 161 193.

FOUCAULT, M. A ordem do discurso. Trad. Eni P. Orlandi. 20. ed. São Paulo: Loyola, 2010.

Grande Enciclopédia Larousse Cultural. São Paulo: Editora Nova Cultural Ltda, 1987, p. 4400. (Círculo do Livro)

Guia de produção textual da PUCRS. Disponível em: http://www.pucrs.br/ gpt/parodia.php

$\mathrm{KOCH}$, I. G. V. A construção de sentidos no texto: intertextualidade e polifonia. In: 0 texto e a construção dos sentidos. São Paulo: Contexto, 1997, p. 46-57. 
Cortez, 2006.

. Desvendando os segredos do texto. 5. ed. São Paulo:

. Introdução à Linguística Textual: trajetória e grandes temas. São Paulo, Martins Fontes, 2004. (Coleção Texto e Linguagem).

; ELIAS, V. M. Ler e Compreender: os sentidos do texto. 2. ed. São Paulo: Contexto, 2008. p. 216.

. Ler e Escrever: estratégias de produção textual. São Paulo: Contexto, 2009.

LARANJEIRA, Ronaldo; PINSKY, Ilana. Como a publicidade de bebidas alcoólicas afeta os mais jovens? INPAD - Instituto Nacional de Políticas Públicas do Álcool e outras Drogas - CNPq - UNIFESP. Apoio: Fapesp 03/06250-7. Disponível em: <http://www.senado.gov.br/comissoes/cas/ ap/AP20081203_BebidasAlcoolicas_USP.pdf>. Acesso em: 24 maio 2013.

MARCUSCHI, L. A. Produção textual, análise de gêneros e compreensão. São Paulo: Cortez, 2008.

Parábola, 2012.

. Linguística de texto: o que é e como se faz. São Paulo:

MENDES, M. F. R. A Análise do Discurso. In: 0 ideário neoliberal na educação a distância em portais de cursos de graduação superior sob o "olhar" da Análise do Discurso (AD). 2013. 106 f. Dissertação (Mestrado em Letras) - Universidade Vale do Rio Verde - UNINCOR, Três Corações. Defesa: 14/03/2013.

ORLANDI, Eni P. Análise de Discurso: princípios e procedimentos. Campinas, SP: Pontes, 2005. p. 100.

PÊCHEUX, M. O discurso: estrutura ou acontecimento. Trad. Eni P. Orlandi. Campinas: Pontes, 1997.

PICOLOTTI, Hamilton. Perspectivas para o setor de bebidas no Brasil em 2013. Disponível em: <http://www.portalnovarejo.com.br/ colunistas/noticias/colunistas/perspectivas-para-o-setor-de-bebidas-nobrasil-em-2013 > . Acesso em: 24 maio 2013.

REINOLD, Matthias R. 0 mercado cervejeiro brasileiro atual potencial de crescimento. Publicado na Revista Indústria de Bebidas, no 57-2011. Disponível em: <http://www.cervesia.com.br/dadosestatisticos/760-o-mercado-cervejeiro-brasileiro-atual-potencial-decrescimento.html>. Acesso em: 24 maio 2013.

ROJO, R. Gêneros do Discurso e Gêneros Textuais: questões teóricas e aplicadas. in: MERURER, J. L.; BONINI, A.; MOTTA-ROTH, D. (org.). 
Gêneros: teorias, métodos, debates. São Paulo: Parábola, 2005, p. 184-207.

SOLÉ, Isabel. Ler, leitura, compreensão: "sempre falamos da mesma coisa?". In TEBEROSKY, Ana; et al. Compreensão de leitura: a língua como procedimento. Trad. Fátima Murad. Porto Alegre: Artmed, 2003. p. 17 - 34. (Coleção Inovação Pedagógica, v.7).

Brasileiro está entre os que mais bebem cerveja no mundo; veja o ranking. Disponível em: <http://economia.uol.com.br/ultimasnoticias/infomoney/2012/08/03/brasileiro-esta-entre-os-que-mais-bebemcerveja-no-mundo-veja-o-ranking.jhtm>. Acesso em: 24 maio 2013.

Recebido em: 09/12/2021

Aceite em: 19/12/2021 